\title{
Analysis of productivity in the Health Care Centers of the Community of Madrid (Spain) 2015-2017
}

\author{
DE JORGE-MORENO, JUSTO \\ Dpto. Economía y Dirección de Empresas. Universidad de Alcalá (Madrid) \\ Correo electrónico: justo.dejorge@uah.es \\ GONZÁlEZ SANTOS, ARANCHA \\ Dpto. Economía y Dirección de Empresas. Universidad de Alcalá (Madrid) \\ Correo electrónico: arancha.gonzalez@uah.es \\ VEGAs MELERO, JOSÉ Jesús \\ Dpto. Economía y Dirección de Empresas. Universidad de Alcalá (Madrid) \\ Correo electrónico: jose.vegas@uah.es \\ Cepeda Olmedo, Martín \\ Dpto. Economía y Dirección de Empresas. Universidad de Alcalá (Madrid) \\ Correo electrónico: martin.cepeda@uah.es
}

\begin{abstract}
The main objective of this work has focused on extending the existing literature on the analysis of total factor productivity of the Health Care Centers (HCC) of the Community of Madrid (Spain) in the period 2015-2017, with two important contributions; the application and comparison of the Malmquist indices with two robust methodologies such as the Hicks-Moorsteen and Färe Primont indices which, except for error, have not been previously used in this sector and the regional scope, which has been scarcely analyzed. The main results reveal decreases in HC productivity due to the three proposed methodologies. These decreases range between $4.90 \%$ and $0.25 \%$ for the Färe-Primont and HicksMoorsteen indices respectively between 2015/17 in average terms. Convergence analyses confirm that this takes place in the case of the Malmquist and HicksMoorsteen proposals.
\end{abstract}

Keywords: productivity, Hicks-Moorsteen Index, Färe-Primont Index, Health Centers. JEL classification: H51; L23; C61.

MSC2010: 90B30; 90B50. 


\title{
Análisis de la productividad en los Centros Sanitarios de la Comunidad de Madrid (España) 2015-2017
}

\begin{abstract}
RESUMEN
El objetivo principal de este trabajo se ha enfocado en extender la literatura existente sobre el análisis de la productividad total de los factores, de los Centros Sanitarios de la Comunidad de Madrid en el periodo 2015-2017, con dos importantes contribuciones, la aplicación y comparación de los índices de Malmquist con dos metodologías robustas, los índices de HicksMoorsteen y Färe Primont que salvo error no han sido previamente utilizadas en este sector y el ámbito regional, que ha sido escasamente analizado. Los principales resultados revelan disminuciones de la productividad de los CS por las tres metodologías propuestas. Estas disminuciones oscilan entre $4.90 \%$ y $0.25 \%$ para los índices de FärePrimont y de Hicks-Moorsteen respectivamente entre 2015/17 en términos medios. Los análisis de convergencia confirman que esta tiene lugar en el caso de las propuestas de Malmquist y Hicks-Moorsteen.
\end{abstract}

Palabras clave: productividad, índice de Hicks-Moorsteen, índice de FärePrimont, centros de salud.

Clasificación JEL: H51; L23; C61.

MSC2010: 90B30; 90B50.

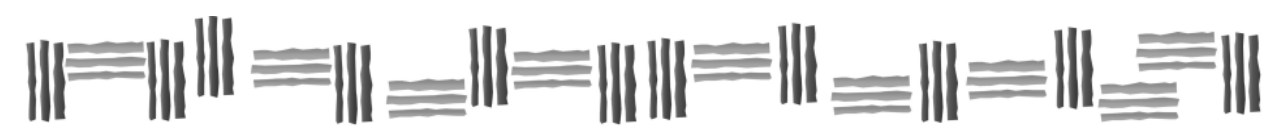




\section{Introduction.}

Spain's healthcare system ranks third in the world, between 200 countries behind Hong Kong and Singapore in terms of efficiency (Vieira, 2018). To hold this position suggests that the Spanish Health System (hereinafter SHS), in particular, manages its resources under criteria of maximizing the quantity and quality of health (Romano \& Choi, 2016).

The competitive situation of the SHS is a challenge, considering the economic crisis and consequent budget cuts and political decisions on welfare (Mateos \& Penedés, 2013). As mentioned, Segura (2014) the restrictive measures carried out in terms of welfare and health policies, could have had negative consequences on public health management. In this sense, the media have reflected the current state of the SHS. For example, Flores (2019) addresses the lack of investment in technological renewal and innovation and its erosion in the SHS. It is surprising that, on the one hand, Spain is among the most efficient countries and, at the same time, ranks 18 th out of the 35 OECD countries in terms of public health expenditure. In addition, Spain allocates $6.3 \%$ of GDP, far from 7.6\%, 9.5\% and 9.6\% from United Kingdom, France, and Germany respectively.

Regarding the Health Care Centers (hereinafter HCC) within SHS, as mentioned GarcíaLatorre et al. (1996) these resemble multi-product organizations where the objective to be fulfilled is the maximization of social efficiency, bearing in mind the criterion of "equity". The analysis of efficiency and productivity in the SHS has received significant attention, as evidenced by the proliferation of studies in recent years. Authors such as Pelone et al. (2015), Barnum et al. (2016) or Vafaee et al. (2018), conduct interesting reviews of international literature on the presence of non-parametric DEA methodologies in the health sector. Likewise, these authors collect the use of output and input variables, as well as the units of analysis used. In relation to the HCC, they have been studied at a national level, among others by García-Latorre et al. (1996) in Aragón (Zaragoza), Puig-Junoy (2000) in Aragón (Zaragoza), Huesca, Navarra and Cataluña, CorderoFerrera et al. (2011) in Extremadura, Cordero-Ferrera et al. (2016) in País Vasco, and Romano and Choi (2016) in Cataluña (Barcelona).

In this context, this work focuses its spatial scope on the Community of Madrid, using the HCCs as analysis, in the period 2015-2017. The main objective is to extend the existing literature on the analysis of total factor productivity (hereinafter TFP) with two important contributions: 1) The application and comparison of the Malmquist index (hereinafter MALM), with two robust methodologies using the TFP index, Hicks-Moorsteen (hereinafter HMTFPC) \& Färe Primont (FPTFPC), which except for errors have not been previously used in this sector; 2) The regional level, which has been scarcely analyzed. In addition, measures of quality of care are incorporated into the analysis.

The work is organized in the following way. In Section 2, the data and methodology are presented. Section 3 shows the results. The fourth section presents the main conclusions.

\section{Data and methodologies.}

\subsection{Data.}

The outputs and inputs have been obtained from the Observatory of the Madrid Health Service (http://observatorioresultados.sanidadmadrid.org/AtencionPrimariaLista.aspx) and supported by literature (see Cordero et al., 2016). Specifically, the outputs include overall customer satisfaction, morbidity, and avoidable hospitalization as a percentage. These two variables have been calculated as a distribution proportional to each HCC, since the values were assigned to the hospitals belonging to them. The inputs in physical or economic units are the health personnel and the overall pharmaceutical expenditure per user. Table 1 shows the descriptive statistics. 
Table 1. Descriptive statistics.

\begin{tabular}{ccc}
\hline Variable & \multicolumn{2}{c}{$2015-2017$} \\
\hline & Mean & SD \\
\cline { 2 - 3 } Customer satisfaction (\%) & 0.9029 & 0.0471 \\
Morbidity (\%) & 0.7317 & 0.0004 \\
Avoidable hospitalization (\%) & 0.0107 & 0.0078 \\
Health personnel (N. of professionals) & 32.689 & 12.279 \\
Pharmaceutical expenditure per user euros) & 11.308 & 0.6610 \\
\hline
\end{tabular}

Source: Prepared by the authors based on the Observatory of the Health Service of Madrid.

\subsection{Methodologies.}

As mention Martinez-Cillero and Thorne (2019), the MALM was initially proposed in the influential article by Caves, Christensen and Diewert (1982), and several authors have provided decompositions of TFP based on this index (Färe et al., 1994; Balk, 2001; Lovell, 2003). Although MALM is widely applied, it faces two important limitations. First, the MALM is not multiplicatively complete since it cannot be expressed as a relationship between a MALM output quantity index and a MALM (O'Donnell, 2008). Because of this, O'Donnell (2008) suggests that it cannot be satisfactorily broken down into significant technical changes, efficiency changes or scale efficiency change components. Second, the MALM does not satisfy transitivity (O'Donnell, 2011). In this sense, authors such as Russell (2018) mention that when comparing the MALM and HMTFPC (or FPTFPC) indexes, the former is a measure of technological change (change in the production frontier) while the latter is a (broader) measure of change in TFP (incorporating the effects of movement along the frontier as well as change in the same) (Grifell-Tatjé \& Lovell, 1995).

In this paper, in line with O'Donnell (2011) to avoid any restrictive and empirically proven assumptions about the technology, the MALM, HMTFPC and FPTFPC indexes are estimated using VRS LPs that allow both technical progress and regression. According to this author, the mathematical approach of these three indexes is the one included in Table 2, where $q, x, t, s$ are the quantities of output, input, and time references respectively (for further details see O'Donnell, 2011).

Table 2. Productivity index for multilateral and multi-temporal comparisons.

\begin{tabular}{|c|c|c|c|}
\hline & Malmquist & Hicks-Moorsteen & Färe-Primont \\
\hline $\begin{array}{l}\text { Output } \\
\text { aggregator } \\
\text { Function }\end{array}$ & $\begin{array}{c}Q(q)=D_{o}\left(x_{i t}, q, t\right) \\
{[\text { Eq 1.1] }}\end{array}$ & $\begin{array}{c}Q(q)=\left[D_{o}\left(x_{h s}, q, s\right) D_{o}\left(x_{i t}, q, t\right)\right]^{1 / 2} \\
{[\mathrm{Eq} 1.2]}\end{array}$ & $\begin{aligned} Q(q) & =D_{o}\left(x_{o}, q, t_{o}\right) \\
& {[\operatorname{Eq~} 1.3] }\end{aligned}$ \\
\hline $\begin{array}{l}\text { Intput } \\
\text { aggregator } \\
\text { function }\end{array}$ & $\begin{array}{c}X(x)=D_{i}\left(x, q_{i t}, t\right) \\
{[\mathrm{Eq} \mathrm{2.1]}}\end{array}$ & $\begin{array}{c}X(x)=\left[D_{I}\left(x, q_{h s}, s\right) D_{I}\left(x, q_{i t}, t\right)\right]^{1 / 2} \\
{[\mathrm{Eq} 2.2]}\end{array}$ & $\begin{aligned} X(x) & =D_{I}\left(x, q_{o}, t_{o}\right) \\
& {[\mathrm{Eq} 2.3] }\end{aligned}$ \\
\hline \multirow{4}{*}{$\begin{array}{l}\text { Productivity } \\
\text { Index }\end{array}$} & $\begin{array}{c}M F P_{h s,}, i t= \\
D .\end{array}$ & $\begin{array}{c}M F P_{h s, i t}= \\
\end{array}$ & $\begin{array}{c}M F P_{h s,}, i t= \\
\end{array}$ \\
\hline & $\overline{D_{o}\left(x_{i t}, q_{h s}, t\right)} \frac{}{D_{I}\left(x_{i t}, q_{i t}, t\right)}$ & 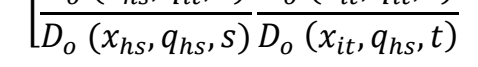 & $D_{o}\left(x_{o}, q_{h s}, t_{o}\right) \frac{1}{D_{I}\left(x_{i t}, q_{o}, t_{o}\right)}$ \\
\hline & & $\left.D_{I}\left(x_{h s}, q_{h s}, s\right) D_{I}\left(x_{h s}, q_{i t}, t\right)\right]^{1 /}$ & \\
\hline & & $\left.\overline{D_{I}\left(x_{i t}, q_{h s}, s\right)} \overline{D_{I}\left(x_{i t}, q_{i t}, t\right)}\right]$ & \\
\hline
\end{tabular}

[Eq 3.1]

[Eq 3.2]

[Eq 3.3] 


\subsection{Comparison of productivity distributions and Convergence.}

Comparison of productivity index distributions will be performed using the Kolmogorov-Smirnov test (KS) (and the graphical function of distributions) and kernel density functions. Finally, a classical convergence regression analysis will be applied, together with a dynamic convergence analysis by means of stochastic kernels.

As suggested by Delgado and Fariñas (2002), the application of the KS test allows us to test the stochastic dominance among the empirical distributions of the HC groups being compared. $\mathrm{F}$ and $\mathrm{G}$ denote the cumulative distribution functions associated with the normalized efficiency corresponding to two groups of HCC to be compared. The stochastic domination of $\mathrm{G}$ over $F$ implies that $F(x) \geq G(x) \forall x \in \Re$ with strict inequality for some $x$. The KS test is appropriate in this case, as it does not require a specific distribution family. The KS test of stochastic domination of $\mathrm{G}$ over $\mathrm{F}$ can be formulated as:

$$
\begin{aligned}
& \text { H0: } F(x)-G(x) \geq 0 \forall x \in \Re<\text { versus } \\
& \text { H1: } F(x)-G(x)<0 \forall x \in \Re
\end{aligned}
$$

To obtain more complete results, the convergence processes will be analyzed in two different ways, for HCC. Firstly, the proposal of the classic of $\beta$-convergence Barro and Sala-iMarti (1992) will be used. This approach is based on analyzing the trend of HCC with relatively low initial levels of TFP to grow relatively faster than the remaining HCC.

The regression proposed in equation 5 (HMTFPC, MALM, FPTFPC), allows to determine the mentioned process, observing the negative sign and the statistical significance of the parameter $\beta$.

$$
\operatorname{Ln} \sum_{t=1}^{T-1}\left(\frac{1}{T-1}\right)\left(\frac{\operatorname{HMTFPC}_{i}^{t+1}}{\operatorname{HMTFPC}_{i}^{t}}\right)=\alpha+\beta \operatorname{Ln} \operatorname{HMTFPC}_{i}^{t}+\varepsilon_{i}
$$

where $\operatorname{HMTFPC}_{i}^{t}$ (or MALM, FPTFPC) \& $\operatorname{HMTFPC}_{i}^{t+1}$ is the productivity index in $2015 / 16$ and $2015 / 17$ respectively. $\beta$ is the parameter to estimate to measure the convergence process.

The classical convergence analysis proposed above is sufficiently informative. However, some authors such as Quah (1997) mention some drawbacks in using this type of methodology due to the lack of information about the internal dynamics of the distribution, since it only picks up some moments of it. In this sense, the use of kernel density functions is usually the most common, to visualize the external form of the distribution. Since efficiency distributions are not normal, the application of these functions makes it possible to avoid important features that might arise. The non-parametric approach, which will be shown below, requires choosing a method to smooth the data. The chosen method is usually kernel smoothing (Scott, 1992).

To capture intradistributional changes or movements, transition matrices could be applied. However, this methodology implies that the results depend on the number and amplitude of the intervals considered. For this reason, authors such as Quah (1997), Stokey and Lucas (1989), prefer to analyze the dynamics within the distribution by means of a continuous approximation based on the use of stochastic kernels, which are nothing more than the equivalent of a transition matrix with a number of intervals that tends to infinity. It is therefore a graphic way of observing the changes, which will also be presented in Section 3. 


\section{Results.}

This section shows the results obtained by applying the three techniques included in the methodologies section. Initially, the average and median values of the output and input variations are presented, as well as the productivity indexes and their components, as reflected in Table 3. Subsequently, comparative analyses of the distributions of the productivity indexes are performed. Finally, the convergence analysis is carried out.

Table 3. Results of the Malmquist, Hicks-Moorsteen \& Färe-Primont indexes.

\begin{tabular}{lc}
\hline & \\
Component & Period \\
\hline Output change & $2015 / 2016$ \\
& $2015 / 2017$ \\
Input change & $2015 / 2016$ \\
& $2015 / 2017$ \\
MALM/HMTFPC/FP & $2015 / 2016$ \\
& $2015 / 2017$ \\
Techn. change & $2015 / 2016$ \\
& $2015 / 2017$ \\
Efficiency change & $2015 / 2016$ \\
& $2015 / 2017$ \\
\hline
\end{tabular}

$$
\text { Malmquist }
$$

\begin{tabular}{ccc} 
Median & Mean & SD \\
\hline 1.0000 & 0.9989 & 0.0068 \\
1.0000 & 0.9998 & 0.0055 \\
1.0000 & 1.0000 & 0.0010 \\
1.0000 & 1.0000 & 0.0004 \\
0.9908 & 0.9918 & 0.0172 \\
1.0003 & 1.0000 & 0.0226 \\
0.9782 & 0.9772 & 0.0099 \\
1.0064 & 1.0057 & 0.0080 \\
1.0138 & 1.0149 & 0.0206 \\
0.9943 & 0.9943 & 0.0239 \\
\hline
\end{tabular}

\section{Hicks-Moorsteen}

\begin{tabular}{ccc} 
Median & Mean & SD \\
\hline 1.0003 & 1.0025 & 0.0143 \\
1.0005 & 1.0000 & 0.0223 \\
1.0103 & 1.0102 & 0.0131 \\
1.0025 & 1.0026 & 0.0118 \\
0.9903 & 0.9924 & 0.0197 \\
1.0001 & 0.9974 & 0.0252 \\
0.9785 & 0.9787 & 0.0113 \\
1.0075 & 1.0038 & 0.0130 \\
1.0103 & 1.0140 & 0.0256 \\
0.9957 & 0.9937 & 0.0279 \\
\hline
\end{tabular}

Source: Own elaboration.

\begin{tabular}{ccc}
\hline \multicolumn{3}{c}{ Färe-Primon } \\
Median & Mean & SD \\
\hline 0.9961 & 0.9944 & 0.0077 \\
0.9961 & 0.9944 & 0.0074 \\
1.0484 & 1.0430 & 0.0603 \\
1.0507 & 1.0457 & 0.0610 \\
0.9497 & 0.9534 & 0.0568 \\
0.9459 & 0.9510 & 0.0573 \\
0.9869 & 0.9869 & 0.0000 \\
0.9902 & 0.9902 & 0.0000 \\
0.9624 & 0.9661 & 0.0576 \\
0.9552 & 0.9604 & 0.0579 \\
\hline
\end{tabular}

Rows 1 and 2 show the output variations, while rows 3 and 4 show the input variations. Rows 5 and 6 show the values of the MALM, HMTFPC and FPTFPC index. In general, the values of the productivity index show levels lower than 1, for the two subperiods. In the case of MALM and HMTFPC there is a timid growth in the case of the median. These results take place, before generally positive variations of the inputs (rows 3 and 4) for HMTFPC and FPTFPC and increases in the outputs (rows 1 and 2) for HMTFPC and decreases for FPTFPC. Productivity decreases are a consequence of both TECHCH and EFFCH, as shown in rows 7 to 10. The FPTFPC methodology shows the greatest deterioration in productivity.

Figure 1 shows the spatial distribution of the ranking of the 25 top HCC (black dots) analyzed according to FPTFPC and HMTFPC parts left and right respectively. There are no coincidences in the hierarchical order of the productivity levels of the two methodologies. Figure 2 and Table 3 show the correlation between the MALM and HMTFPC indexes and the difference with the FPTFPC index for 2015/2017 (in the case of 2015/16 the patterns are similar). 
Figure 1. Spatial distribution of the 25 top HCC according to the HMTFPC and FPTFPC methodology.

Färe Primont

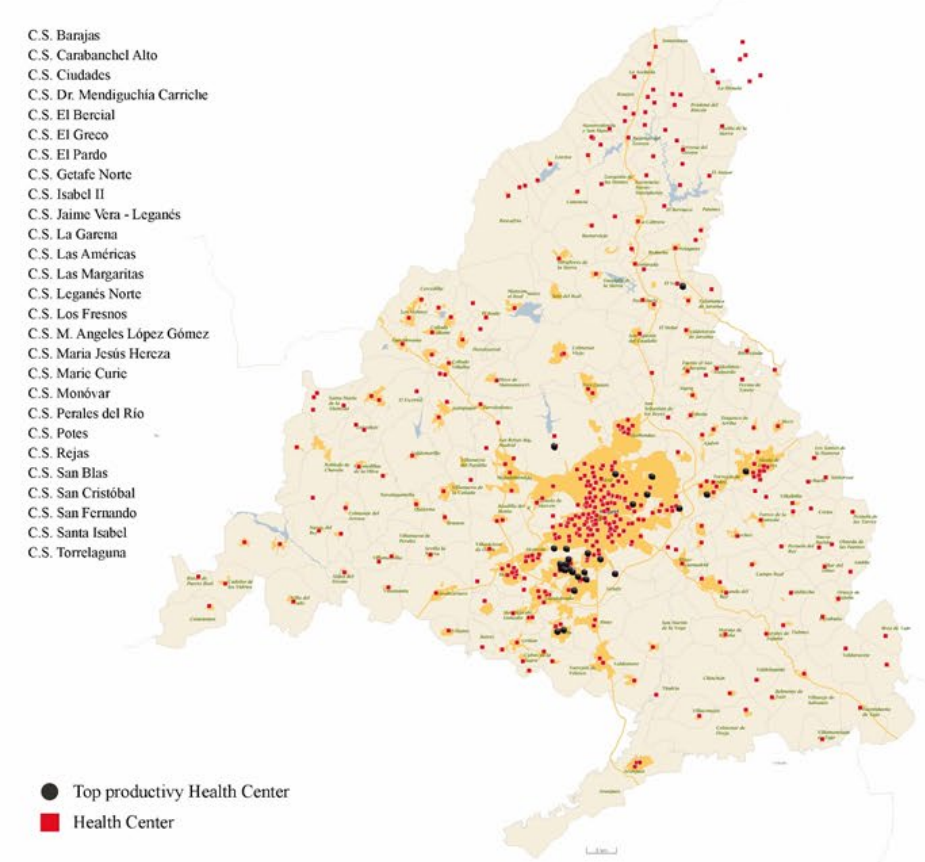

Hicks-Moorsteen

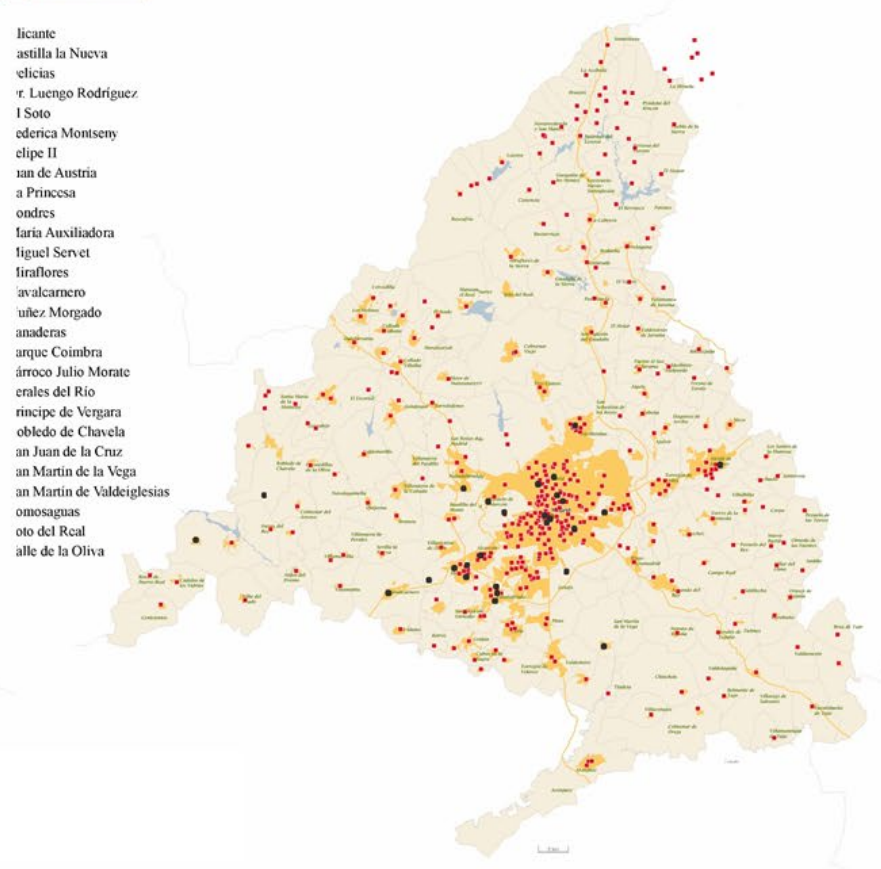

Source: http://centrossanitarios.sanidadmadrid.org/, Wikipedia and own elaboration. 
Figure 2. Dispersion diagrams of productivity index.

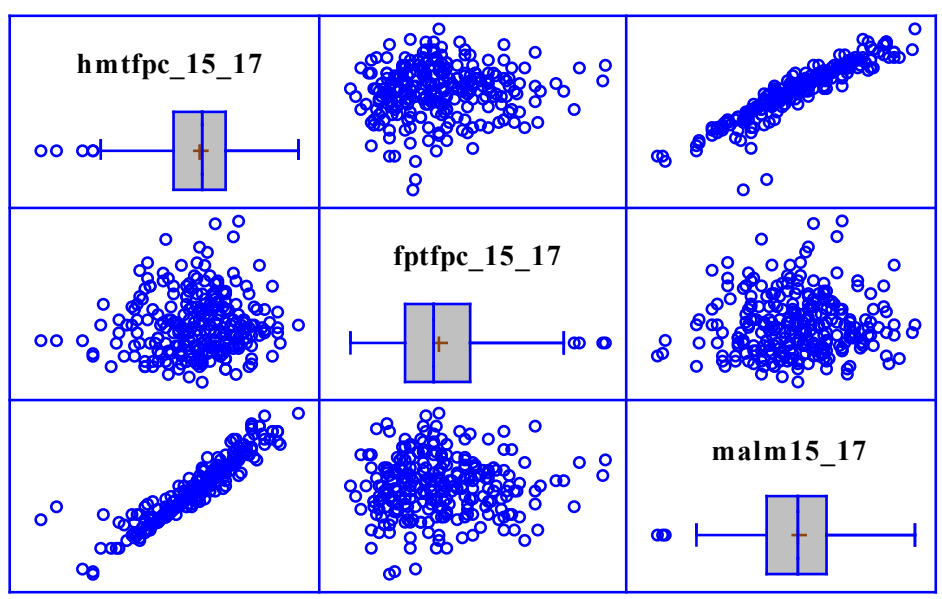

Source: Own elaboration.

Table 3 shows the high and significant correlation between the HMTFPC and MALM indexes and the no correlation between these and FPTFPC.

Table 3. Correlations between productivity index.

\begin{tabular}{cccc}
\hline & hmtfpc_15_17 & fptfpc 15_17 & malm15 17 \\
\hline hmtfpc_15_17 & & 0.0673 & 0.9274 \\
& & $(262)$ & $(262)$ \\
fptfpc_15_17 & 0.0673 & 0.2780 & 0.0000 \\
& $(262)$ & & 0.0356 \\
malm15_17 & 0.2780 & $(262)$ \\
& 0.9274 & 0.0356 & 0.5663 \\
& $(262)$ & $(262)$ & \\
& 0.0000 & 0.5663 & \\
& \multicolumn{3}{c}{ Correlation } \\
& \multicolumn{3}{c}{ (Sample size) } \\
& PValue &
\end{tabular}

Source: Own elaboration.

\subsection{Comparison of Distributions, Kernel Density Functions and Convergence.}

Figure 3 shows the kernel density distributions in the left column and the comparison and dominance analyses in the right column. The results shown through the kernel distributions indicate that productivity of HMTFPC and MALM of the subperiod 2015/17 is shifted ahead of the subperiod 2015/16, denoting convergence. In the case of FPTFPC, no changes occur. Likewise, the 2015/17 productivity distribution dominates the $2015 / 16$ productivity distribution in HMTFPC and MALM as shown in the graphs in the right-hand column of Figure 3. In the case of FPTFPC distributions, there is no dominance. 
Figure 3. Kernel distributions and statistical dominance.
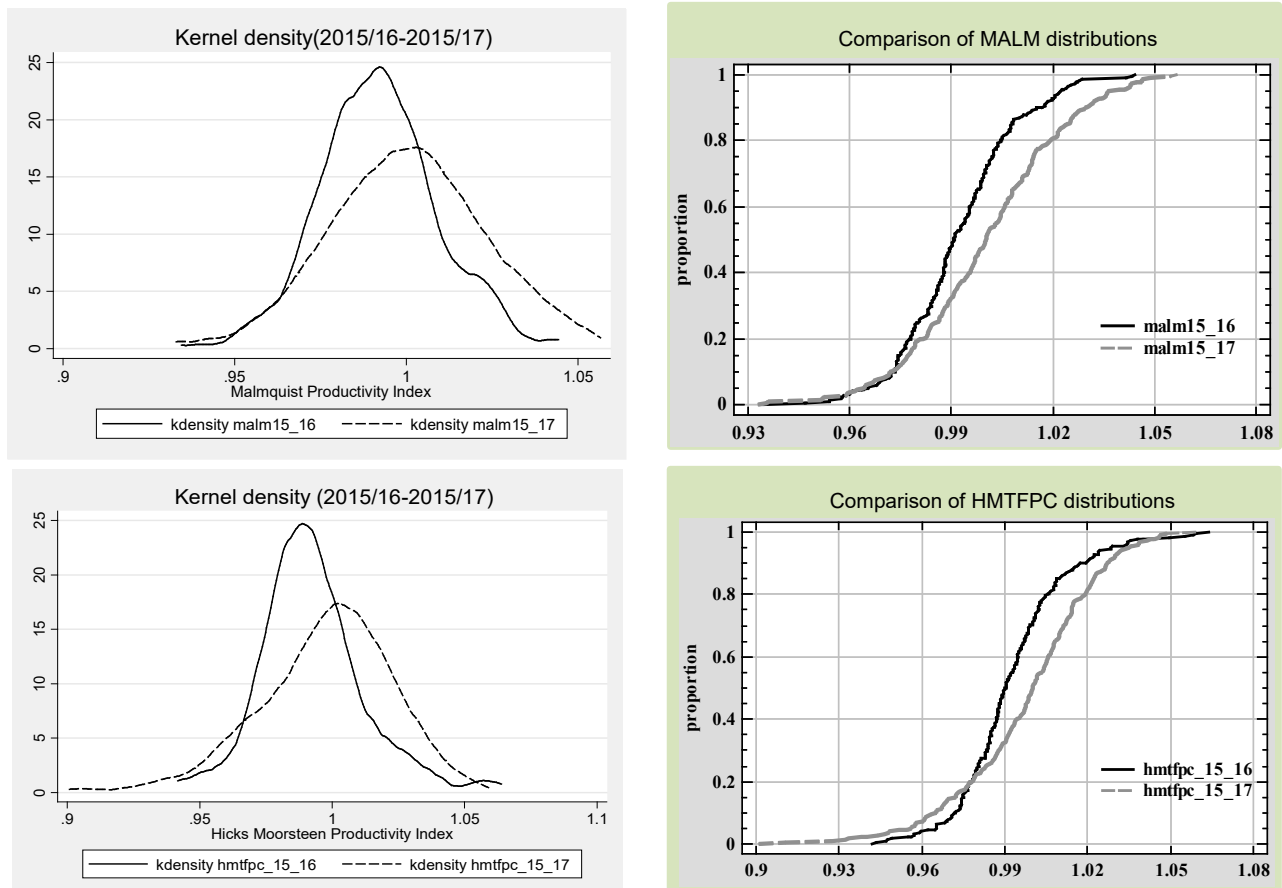

Kernel density (2015/16-2015/17)
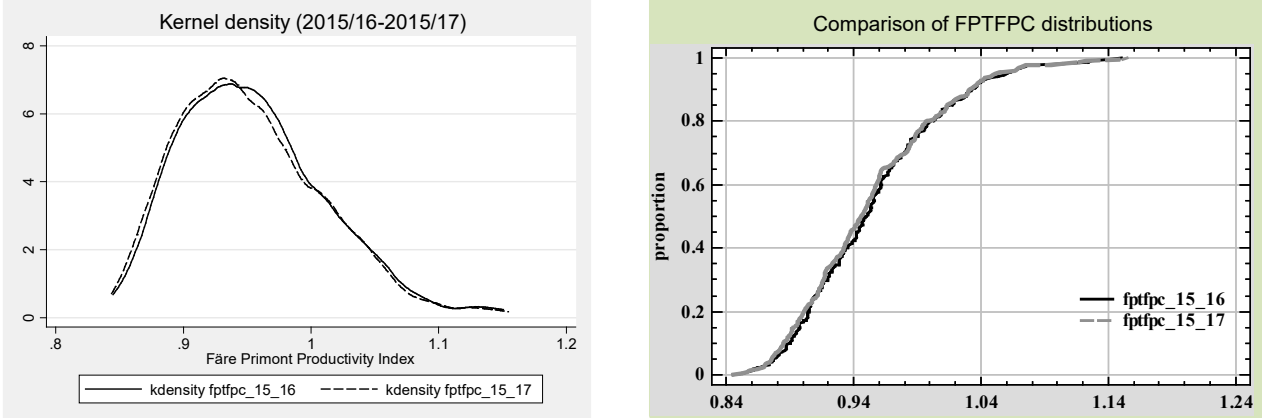

Source: Own elaboration.

Table 4 shows the tests and statistical significance.

Table 4. Kolmogorov-Smirnov statistical dominance test.

\begin{tabular}{ccc}
\hline $2015 / 16$ vs $2015 / 17$ & KS test & Pvalue \\
\hline Malmquist & 0.2405 & 0.0000 \\
Hicks-Moorsteen & 0.2328 & 0.0000 \\
Färe-Primont & 0.0458 & 0.9340 \\
\hline
\end{tabular}

Source: Own elaboration

We begin with $\beta$ convergence. The idea is to determine if the trend of the $\mathrm{HC}$ with lower productivity levels, grow faster than the others, as already commented. The results of Table 5 show that coefficients -0.2638 and -0.2611 are significant at $1 \%$ for MALM and HMTFPC respectively, indicating that the least productive $\mathrm{HC}$ of each group in the initial subperiod, in general, have obtained productivity growths than most of the $\mathrm{HC}$ in that subperiod. 
Table 5. Regression analysis of productivity index to the initial 2015/16.

\begin{tabular}{|c|c|c|c|}
\hline & cons & $\begin{array}{c}\beta \text {-coefficient } \\
\text { bootstrap Std. Err. }\end{array}$ & Adj $R^{2}$ \\
\hline LnMALM & $\begin{array}{l}-0.0022 \\
(0.0016)\end{array}$ & $\begin{array}{c}-0.2638 * * \\
(0.0838)\end{array}$ & 0.0372 \\
\hline LnHMTFPC & $\begin{array}{l}-0.0045 \\
(0.0017)\end{array}$ & $\begin{array}{c}-0.2611 * * \\
(0.0791)\end{array}$ & 0.0409 \\
\hline LnFPTFPC & $\begin{array}{l}-0.0031 \\
(0.0009)\end{array}$ & $\begin{array}{c}0.0988 \\
(0.0130)\end{array}$ & 0.9570 \\
\hline
\end{tabular}

CInf: Conventional inference. Inference based on non-corrected var-cov Matrix BInf: Bootstrapping inference. Inference based on varcov, corrected by Bootstrap method $(\mathrm{L}=2000)$ Source: Own elaboration.

Finally, Figure 4 shows the convergence made through stochastic kernels according to the contour graphics approach. As can be seen, for the MALM and HMTFPC methodologies the probalistic mass and therefore the intradistributional changes are mostly located above the diagonal, confirming convergence. Whereas with the FPTFPC methodology, the probalistic mass is placed on the diagonal, confirmed stagnation.

Figure 4. Stochastic kernels: contour plot.
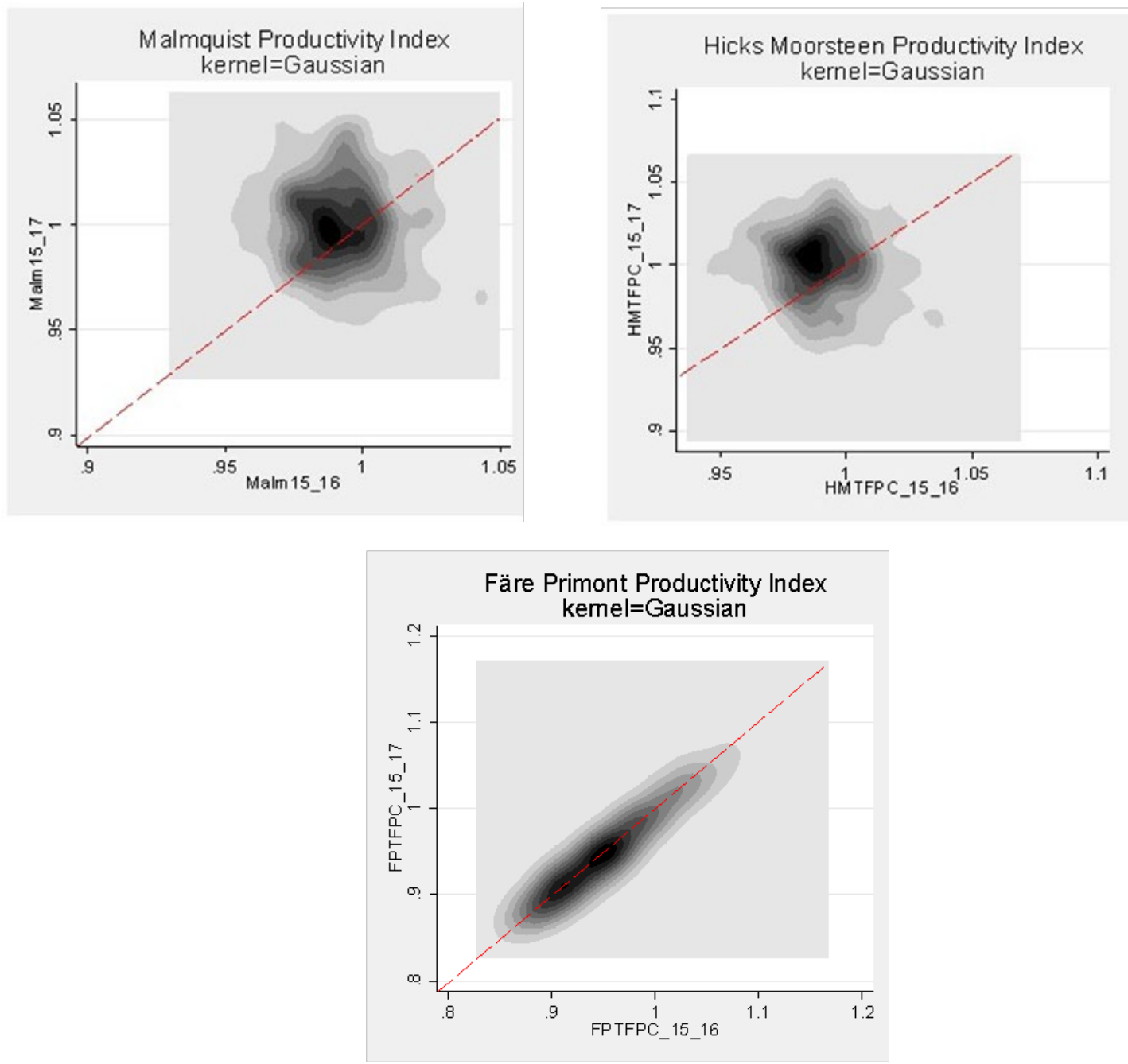

Source: Own elaboration. 


\section{Conclusions.}

A productivity analysis has been carried out from a public database on $\mathrm{HC}$ in the Community of Madrid, the capital of Spain. The main objective of this work has focused on extending the existing literature, on the analysis of total factor productivity, with two important contributions: 1) The application and comparison of two robust methodologies, by means of the index, of total factor productivity of HicksMoorsteen \& Färe Primont which, except for error, have not been previously used in this sector; 2) The regional scope, which has been scarcely analyzed.

The main results reveal decreases in HCC productivity due to the three proposed methodologies. These decreases range between $4.90 \%$ and $0.25 \%$ for the Färe-Primont \& Hicks-Moorsteen index respectively between 2015/17 in average terms. Convergence analysis confirm that this takes place in the case of the Malmquist \& Hicks-Moorsteen proposals.

The health budget in Spain is approximately $43 \%$ in three regions, where the Community of Madrid is located. The health budget of Madrid in terms of public expenditure per inhabitant is among the three lowest in Spain, in the period of analysis studied. In terms of public policy recommendations and managerial decisions, it should be mentioned that the consequences of the crisis, in terms of higher levels of poverty and unemployment, could require greater efforts at health intervention in the search for higher levels of social efficiency. It seems evident that the maintenance of a world-class position of excellence in the Spanish healthcare system depends on continuing to improve, optimising resources but also providing them.

\section{References}

Balk, B.M. (2001). Scale Efficiency and Productivity Change. Journal of Productivity Analysis, 15(3), 159-183.

Barnum, D., Johnson, M., \& Gleason, J.M. (2016). Importance of Statistical Evidence in Estimating Valid DEA Scores. Journal of Medical System, 40, 47-59.

Barro, R.J., \& Sala-i-Martin, X. (1992). Convergence. Journal of Political Economics, 100(2), 223251.

Caves, D. W., Christensen, L. R., \& Diewert. W. E. (1982). The Economic Theory of Index Numbers and the Measurement of Input, Output, and Productivity. Econometrica, 50 (9), 1393-1414.

Cordero-Ferrera, J.M., Nuño-Solinis, R., Orueta, J.F., Polo, C., Del Rio-Cámara, M., \& Alonso-Morán, E. (2016). Evaluación de la eficiencia técnica de la atención primaria pública en el País Vasco, 2010-2013. Gaceta Sanitaria, 30(2), 104-109.

Cordero-Ferrera, J.M., Crespo-Cebada, E., \& Murillo-Zamorano, L.R. (2011). Measuring technical efficiency in primary health care, The Effect of exogenous variables on results. Journal of Medical System, 35, 545-554.

Delgado, M., \& Fariñas, J.C. (2002). Firm productivity and export markets, a non-parametric approach. Journal of International Economics, 57(2) 397-422.

Färe, R., Grosskopf, S., Norris, M., \& Zhang, Z. (1994). Productivity Growth, Technical Progress and Efficiency Change in Industrialized Countries. American Economic Review, 84(1), 66-83.

Flores, I. (2019, $24 \quad$ April). Bajo mínimos. Retrieved from https,//elpais.com/elpais/2019/04/23/opinion/1556042649_143602.html 
García-Latorre, F., Marcuello, C., Serrano, G.D., \& Urbina, O. (1996) Evaluación de la eficiencia en centros de atención primaria. Una aplicación del análisis envolvente de datos. Revista Eso Salud Publica, 70, 211-220.

Grifell-Tatjé, E., \& C.A. Lovell, K. (1995). A note on the Malmquist index. Economics Letters, 47(2) $169-175$

Lovell, C.K. (2003). The Decomposition of Malmquist Productivity Index. Journal of Productivity Analysis, 20(3), 437-458.

Martínez-Cillero, M., \& Thorne, F. (2019). Sources of productivity growth using the Färe-Primont decomposition. An empirical application to the Irish beef sector. Applied Economics, 51(36), 3982-3994.

Mateos, A., \& Penedés, A. (2013). España, Crisis y recortes. Revista de ciencia política, 33(1), 161183.

O’Donnell, C.J. (2008). An Aggregate Quantity-Price Framework for Measuring and Decomposing Productivity and Profitability Change. Working paper series, No. WP07/2008, University of Queensland.

O'Donnell, C.J. (2011). Econometric Estimation of Distance Functions and Associated Measures of Productivity and Efficiency Change. Centre for Efficiency and Productivity Analysis Working Papers WP01/2011. University of Queensland.

Pelone, F., Kringos, D.S., Romaniello, A., Archibugu, M., Salsiri, C., \& Ricciardi, W. (2015). Primary Care Efficiency Measurement Using Data Envelopment Analysis. A Systematic Review Journal of Medical System, 39(1), 156-177.

Puig-Junoy, J. (2000). Eficiencia en la atención primaria de salud, Una revisión crítica de las medidas frontera. Revista Española de Salud Pública, 74, 483-495.

Quah, D.T. (1997). Empirics for Growth and Distribution, Stratification, Polarization and Convergence Clubs. Journal of Economic Growth, 2, 27-59.

Romano, J., \& Choi, Á. (2016). Medida de la eficiencia de la atención primaria en Barcelona incorporando indicadores de calidad. Gaceta Sanitaria, 30(5), 359-365.

Russell, R. (2018). Theoretical productivity index. The Oxford handbook of productivity analysis. Oxford: Emili Grifell-Tatjé, C. A. Knox Lovell, \& Robin C. Sickles. DOI: 10.1093/oxfordhb/9780190226718.013.4.

Scott, D.W. (1992). Multivariate density estimation; Theory, practice, and visualization. New York: Wiley.

Segura, A. (2014). Recortes, austeridad y salud. Gaceta Sanitaria, 28(S1), 7-11.

Stokey, N.L., \& Lucas, R.E. (1989). Recursive methods in Economics Dynamics. Massachussets: Harvard University Press.

Vafaee, A., Pooya, A., Alizadeh, A., \& Emrouznejad, A. (2018). Assessing the Relative Performance of Nurses Using Data Envelopment Analysis Matrix (DEAM). Journal of Medial System, 42, 125-134. 
Vieira, M., (2018, 24 September). España tiene el sistema sanitario más eficiente de Europa y el tercero del mundo, según el informe Bloomberg, Diario Enfermero. Retrieved from http,//diarioenfermero.es/espana-tiene-el-sistema-sanitario-mas-eficiente-de-europa-y-eltercero-del-mundo-segun-el-informe-bloomberg/ 